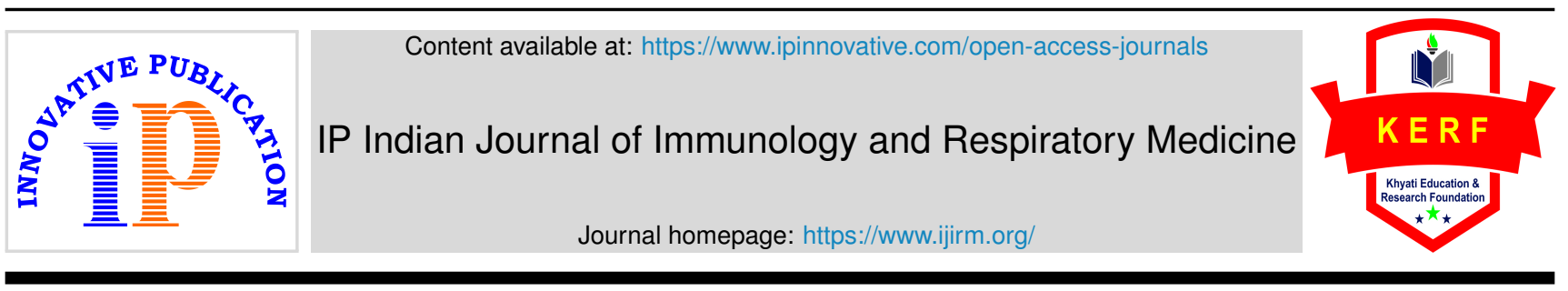

Original Research Article

\title{
Association between obesity and c reactive protein among patients with risk factors for cardiovascular disease
}

\author{
Ch Bhadra Reddy ${ }^{1} *$, Kunachgi Preeti Nagkumar', M Hima Bindu², \\ Chinthaparthi Mallikarjuna Reddy ${ }^{2}$ \\ ${ }^{1}$ Dept. of General Medicine, Mallareddy Institute of Medical Sciences, Suraram, Hyderabad, Telangana, India \\ ${ }^{2}$ Dept. of Microbiology, Mallareddy Institute of Medical Sciences, Suraram, Hyderabad, Telangana, India
}

\section{A R T I C L E I N F O}

\section{Article history:}

Received 19-02-2021

Accepted 24-04-2021

Available online 07-06-2021

\section{Keywords:}

Obesity

Overweight

BMI

C Reactive Protein

\begin{abstract}
A B S T R A C T
Background: One of the main markers of inflammation is $\mathrm{C}$ reactive protein, which is normally raised in patients with myocardial infarction, vascular diseases, stroke or sudden cardiac death. Obesity is associated with a raised CRP level probably due to the cytokine stimulation by the adipose tissues. Elevated CRP with an addition of overweight / obesity is a risk factor for cardiac disorders.

Materials and Methods: Demographic details were taken from 371 patients with cardiovascular risk factors and blood was sent for CRP and lipid profile. Height and weight were noted for the calculation of BMI.

Results: The mean age of the males was $48.37 \pm 8.92$ years and of the females the same was $45.72 \pm$ 6.23 years, the male to female ratio was $2.1: 1.38 .8 \%$ of the people were under normal weight, $39 \%$ were overweight and $22.1 \%$ were obese. A majority of the overweight patients $(61.4 \%)$ had elevated CRP levels, and $10.3 \%$ had clinically raised CRP levels. Amongst the obese patients, $43.9 \%$ had clinically raised CRP levels while $35.4 \%$ had elevated CRP levels.

Conclusions: The is a strong association between the increase in weight among the patients and elevated CRP levels Both these two are not only the risk factors of CVD, but also the cause of depression and reduced quality of life among the individuals.
\end{abstract}

(C) This is an open access article distributed under the terms of the Creative Commons Attribution License (https://creativecommons.org/licenses/by/4.0/) which permits unrestricted use, distribution, and reproduction in any medium, provided the original author and source are credited.

\section{Introduction}

Inflammation of the arteries is one of the causes of atherosclerosis. ${ }^{1,2}$ One of the main markers of inflammation is $\mathrm{C}$ reactive protein, which is normally raised in patients with myocardial infarction, vascular diseases, stroke or sudden cardiac death. ${ }^{3,4}$

Adipose tissue earlier used to have a passive role in storage of fat in the body, but now it is known to play an active role in its metabolism. ${ }^{5,6}$ One of the compounds that is released into the blood circulation by the adipose tissues is the proinflammatory cytokine interleukin (IL6). ${ }^{7,8}$ About $25 \%$ of the IL6 produced in the body is secreted by the adipose tissues. $^{9}$

\footnotetext{
* Corresponding author.

E-mail address: cpmreddy@gmail.com (C. B. Reddy).
}

The incidence of overweight and obese persons in increasing worldwide probably due to inactivity of the people with very less physical activity, change of life style and diet. This is seen more so among the children and adolescents, where in the subjects prefer to be indoors with internet rather that physical exercise outdoors. This may lead in atherosclerosis and elevated blood pressure as they grow older. ${ }^{10}$ In the United states alone it is reported that $>50 \%$ of the adults are overweight and around one in every five individuals is obese. The fatality rates among the obese individuals is also high. ${ }^{11,12}$

Obesity is associated with a raised CRP level probably due to the cytokine stimulation by the adipose tissues. Elevated CRP with an addition of overweight/obesity is a risk factor for cardiac disorders. Other independent factors 
for the cardiovascular diseases are diabetes, hypertension, and insulin resistance. Elevated CRP for longer periods is a feature of acute inflammation, probably due to an ongoing inflammation, and must be differentiated from chronic infection. Therefore, a CRP test must be done to confirm after 2 weeks of the first test.

We had performed this study to assess the association between obesity and elevated levels of CRP.

\section{Materials and Methods}

This cross sectional study was performed by the Department of Medicine and Microbiology at Mallareddy Institute of Medical Sciences from June 2019 to September 2021. This study was cleared by the institutional Ethical Committee. 371 patients with cardiovascular risk factors who had come to our hospital for treatment were explained the nature of the study in detail and were enrolled into the study after obtaining the informed consent. A detailed medical history was taken for all the patients and demographic details were also noted. All pregnant women were excluded from the study and patients who had overt inflammatory diseases were also excluded. Patients who were on drugs for hypertension or diabetes mellitus were also excluded from the study.

All the patients were asked about history of smoking, alcoholism, familial status diabetes etc. and the details were noted. The height and weight of the patients was taken and body mass index was calculated.

Blood was collected by phlebotomy and was sent for tests such as complete blood picture, random blood sugar levels, Hbalc, Lipid profile and $\mathrm{C}$ reactive protein levels. $\mathrm{C}$ reactive protein was estimated using chemiluminescence and a value of $\leq 0.22 \mathrm{mg} / \mathrm{dL}$ was considered to be normal, between 0.22 and $1.00 \mathrm{mg} / \mathrm{dL}$ was considered elevated and more than $1.00 \mathrm{mg} / \mathrm{dL}$ was considered to be clinically raised levels for CRP.

\section{Results}

371 patients were included into the study, out of which 252 $67.9 \%)$ patients were males and $119(32.1 \%)$ were females. The mean age of the males was $48.37 \pm 8.92$ years and of the females the same was $45.72 \pm 6.23$ years. The body mass index was normal in $105(41.67 \%)$ males and in $39(32.8 \%)$ females, while $92(36.5 \%)$ and $53(44.5 \%)$ of males and females respectively were overweight and $55(21.8 \%)$ of the males and $7(22.7 \%)$ of the females were obese. $48(19.1 \%)$ males and $7(5.9 \%)$ females were regular smokers but 101 $(40.1 \%)$ males and $88(73.9 \%)$ females never smoked. 43 $(17.1 \%)$ and $31(26.1 \%)$

Of males and females had inflammatory diseases and 66 (26.2\%) and $52(43.7 \%)$ males and females had a history of cardiovascular disease. Contraceptive use was seen in $31(26.1 \%)$ females and $9(7.6 \%)$ of them had hormone replacement therapy (Table 1$)$.

Table 1: Demographic variables among the males and females under study

\begin{tabular}{|c|c|c|}
\hline Variables & Male & Female \\
\hline Number & $252(67.9 \%)$ & $119(32.1 \%)$ \\
\hline $\begin{array}{l}\text { Age (Mean in years } \\
\pm \text { SD) }\end{array}$ & $48.37 \pm 8.92$ & $45.72 \pm 6.23$ \\
\hline \multicolumn{3}{|l|}{ BMI } \\
\hline $\operatorname{Normal}\left(<25 \mathrm{~kg} / \mathrm{m}^{2}\right)$ & $105(41.67 \%)$ & $39(32.8 \%)$ \\
\hline $\begin{array}{l}\text { Overweight (25-29 } \\
\left.\mathrm{kg} / \mathrm{m}^{2}\right)\end{array}$ & $92(36.5 \%)$ & $53(44.5 \%)$ \\
\hline Obese $\left(\geq 30 \mathrm{~kg} / \mathrm{m}^{2}\right)$ & $55(21.8 \%)$ & $27(22.7 \%)$ \\
\hline \multicolumn{3}{|l|}{ Smoking Status } \\
\hline Regular & $48(19.1 \%)$ & $7(5.9 \%)$ \\
\hline Occasional & $103(40.9 \%)$ & $24(20.2 \%)$ \\
\hline Never & $101(40.1 \%)$ & $88(73.9 \%)$ \\
\hline \multicolumn{3}{|l|}{ Alcohol Status } \\
\hline Regular & $29(11.5 \%)$ & $9(7.6 \%)$ \\
\hline Occasional & $92(36.5 \%)$ & $21(17.6 \%)$ \\
\hline Never & $131(52 \%)$ & $89(74.8 \%)$ \\
\hline $\begin{array}{l}\text { Familial history of } \\
\text { diabetes }\end{array}$ & $149(59.1 \%)$ & $77(64.7 \%)$ \\
\hline \multicolumn{3}{|l|}{$\begin{array}{l}\text { History of comorbid } \\
\text { diseases }\end{array}$} \\
\hline Inflammatory diseases & $43(17.1 \%)$ & $31(26.1 \%)$ \\
\hline Cardiovascular diseases & $66(26.2 \%)$ & $52(43.7 \%)$ \\
\hline Diabetes & $102(40.5 \%)$ & $69(58 \%)$ \\
\hline Hypothyroidism & $76(30.2 \%)$ & $61(51.3 \%)$ \\
\hline \multicolumn{3}{|l|}{ Estrogen use } \\
\hline None & & $79(66.4 \%)$ \\
\hline Contraceptives & & $31(26.1 \%)$ \\
\hline Hormone replacement & & $9(7.6 \%)$ \\
\hline
\end{tabular}

$106(73.6 \%)$ of the patients who had normal BMI had undetectable levels of CRP, while $36(25 \%)$ of them had elevated CRP levels and only 2(1.4\%) people with normal BMI had clinically raised CRP levels. However, among the overweight people, a majority of them had elevated CRP levels, with $89(61.4 \%)$ and $15(10.3 \%)$ had clinically raised CRP levels. Amongst the obese patients, 36(43.9\%) had clinically raised CRP levels while $29(35.4 \%)$ had elevated CRP levels (Figure 1). Only 17(13.9\%) had normal levels.

\section{Discussion}

Obesity is one of the most common condition which impairs health and quality of life among the people, not to mention leading to depression. This condition, along with other risk factors, lead to atherosclerosis and cardiovascular diseases. Apart from obesity, low grade inflammation is also said to be a risk factor. ${ }^{13,14}$

In this study, we assessed the increased CRP levels among the increase in weight of the patients. The number of males in our study was higher than the females with a male to female ratio of 2.1:1. However, more percentage of women than men were either overweight or obese. This 


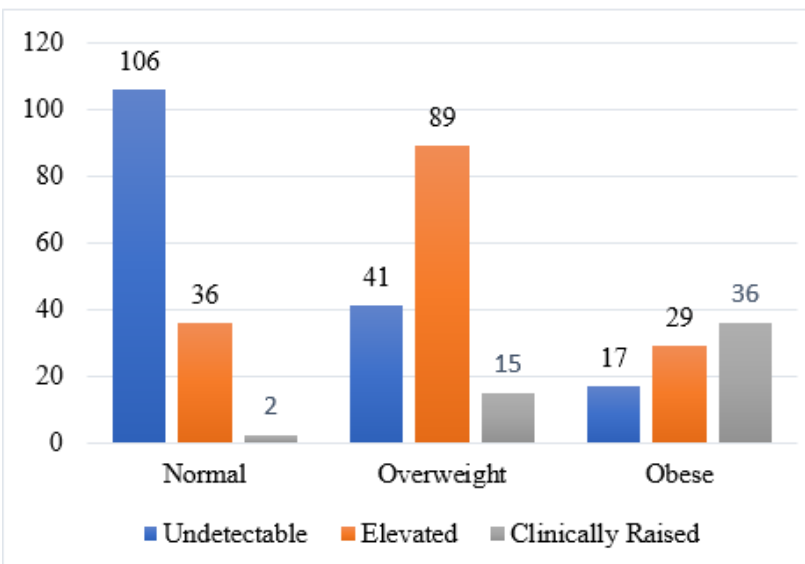

Fig. 1: CRP levels based on BMI

could be because the men are more accessible to physical work, while the women mostly have a lesser amount of physical activity.

A positive association of elevated CRP levels and BMI was observed among the patients. Elevated CRP levels were seen in most of the overweight people and among obese patients, most were clinically raised CRP levels. A similar case was observed in a study by Aronson et al in Israel, who also reported a higher level of CRP concentrations among the patients with metabolic syndrome. Within crease in the metabolic disorders, they observed increase in the CRP levels. ${ }^{15}$ Similar results were observed in other studies also. ${ }^{16-19}$ A study by Nishide et al.,on children also reported a higher level of CRP among the obese children in comparison to the non-obese children. ${ }^{20}$ A positive association between the Body intraabdominal adipose tissue, fat free mass and body fat and was found by Tchernof et al., ${ }^{21}$ An association of elevated CRP was found to the visceral fat accumulation by Lemieux et al. ${ }^{22}$

Around $34 \%$ of the patients were on estrogen therapy. It was observed that such women were at greater risk of developing low grade inflammation. ${ }^{23}$

More number of persons who had normal BMI in our study had normal levels of raised CRP levels. Similar results were observed by Aronson et al, where they observed that the patients who did not have metabolic syndromes did not have elevated CRP levels corroborating our study. ${ }^{15}$

The increased CRP levels among the obese patients is attributed to the body fat. TNF $-\alpha$ and IL- 6 are released by the adipose tissues and since there is a close association between the cytokines and CRP, as well as CRP and obesity, the levels are elevated. ${ }^{19,22}$ It is believed that Interleukin -6 which is released by the adipose tissue is the regulator of the CRP levels and in insulin resistant and obese individuals, it is the cause for the rise in the CRP levels. ${ }^{24}$

Low grade inflammation and obesity was also reported to be one of the causes of health related depression. A study by Meyer et al reported that obese patients who had depressive moods also had elevated CRP levels. ${ }^{25}$ Christian et al also reported that in elderly, the poor self-rated health is associated with an elevated CRP levels and IL-6 levels and thereby affecting the quality of life. ${ }^{23}$

\section{Conclusions}

There is a strong association between the increase in weight among the patients and elevated CRP levels. Higher CRP levels denote an infection or inflammation and is more common among the obese patients. Both these two are not only the risk factors of CVD, but also the cause of depression and reduced quality of life among the individuals. Therefore, an early detection is necessary to prevent CVD and improve quality of life.

\section{Acknowledgement}

None.

\section{Source of Funding}

No financial support was received for the work within this manuscript.

\section{Conflict of Interest}

The authors declare that they have no conflict of interest.

\section{References}

1. Ross R. Atherosclerosis Fan inflammatory disease. $N$ Engl J Med. 1999;340:115-26.

2. Libby P, Ridker PM, Maseri A. Inflammation and Atherosclerosis Circulation. 2002;105(9):1135-43. ब01:10.16/hc00(02 104353.

3. Ridker PM. High-sensitivity C-reactive protein: potential adjunct for global risk assessment in the primary prevention of cardiovascular disease. Circulation. 2001;103:1813-8.

4. Ridker PM. Clinical Application of C-Reactive Protein for Cardiovascular Disease Detection and Prevention. Circulation.

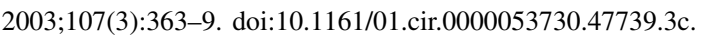

5. Flier JS. The adipocyte: Storage depot or node on the energy information superhighway? Cell. 1995;80(1):15-8. 10:10.106 $8674(95) 90445-\mathrm{X}$

6. Mohamed-Ali V, Pinkney JH, Coppack SW. Adipose tissue as an endocrine and paracrine organ. Int J Obes Relat Metab Disord. 1998;22(12):1145-58. do1:10.1038/s].1jo.0800770.

7. Purohit A, Ghilchik MW, Duncan L, Wang DY, Singh A, Walker MM, et al. Aromatase activity and interleukin- 6 production by normal and malignant breast tissues. J Clin Endocrinol Metab. 1995;80(10):3052_ 8. do1:10.1210/jcem.80.10.7559896

8. Ali VM, Goodrick S, Rawesh A. Subcutaneous adiporse tissue releases interleukin - 6 but nit tuomor necrosis factor- $\alpha$ in vivo. $J$ Clin Endocrinol Metab. 1997;82:4196-200.

9. Fried SK, Bunkin DA, Greenberg AS. Omental and subcutaneous adipose tissues of obese subjects release interleukin - 6. J Clin Endocrinol Metab. 1998;83:847-50.

10. Rani PR, Maheshwari R, Namburi RP, Ponnala AR, Karthik TS. A study on metabolic variables and its association with high sensitive Creactive protein in obese children and adolescents. Indian $\mathrm{J}$ Endocr Metab. 2013;17(7):360-2. 601:10.4103/2230-8210. 10623.

11. Allison DB, Fontaine KR, Manson JE, Stevens J, Vanitallie TB Annual deaths attributable to obesity in the United States. JAMA 1999;282:1530-8. 
12. Willett WC, Dietz WH, Colditz GA. Guidelines for Healthy Weight. $\quad N$ Engl J Med. 1999;341(6):427-34. doi:10.1056/nejmI99908053410607.

13. Ridker PM, Buring JE, Shih J, Matias M, Hennekens CH. Prospective Study of C-Reactive Protein and the Risk of Future Cardiovascular Events Among Apparently Healthy Women.

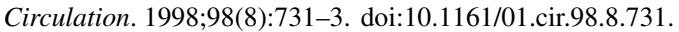

14. Koenig W, Sund M, Frohlich M, Fischer HG, Löwel H, Döring A, et al. C-reactive protein, a sensitive marker of inflammation, predicts future risk of coronary heart disease in initially healthy middle-aged men. Circulation. 1999;99:237-42.

15. Aronson D, Bartha P, Zinder O, Kerner A, Markiewicz W, Avizohar O, et al. Obesity is the major determinant of elevated C-reactive protein in subjects with the metabolic syndrome. Int J Obest. 2004;28(5):674-9. d01:10.1038/s].1]0.0802609

16. Frohlich M, Imhof A, Berg G, Hutchinson WL, Pepys MB, Boeing $\mathrm{H}$, et al. Association between $\mathrm{C}$-reactive protein and features of the metabolic syndrome: a population-based study. Diabetes Care. 2000;23(12):1835-9. [0i:1022337/diacare.23.12.1835

17. Festa A, D'Agostino R, Howard G, Mykkänen L, Tracy RP, Haffner SM, et al. Chronic Subclinical Inflammation as Part of the Insulin Resistance Syndrome. Circulation. 2000;102(1):42-7.

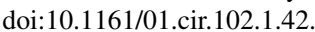

18. Hak AE, Stehouwer CDA, Bots ML, Polderman KH, Schalkwijk CG, Westendorp ICD, et al. Associations of CReactive Protein With Measures of Obesity, Insulin Resistance, and Subclinical Atherosclerosis in Healthy, Middle-Aged Women. Arterioscler Thromb Vasc Biol. 1999;19(8):1986-91.

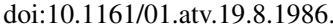

19. Yudkin JS, Stehouwer CD, Emeis JJ, Coppack SW. C-reactive protein in healthy subjects: associations with obesity, insulin resistance, and endothelial dysfunction: a potential role for cytokines originating from adipose tissue? Arterioscler Thromb Vasc Biol. 1999;19:972-8.

20. Nishide R, Ando M, Funabashi H, Yoda Y, Nakano M, Shima M, et al. Association of serum hs-CRP and lipids with obesity in school children in a 12-month follow-up study in Japan. Environ Health Prev

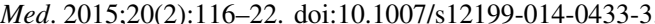

21. Tchernof A, Nolan A, Sites CK, Ades PA, Poehlman ET. Weight Loss Reduces C-Reactive Protein Levels in Obese Postmenopausal Women. Circulation. 2002;105(5):564-9. 10:-10. $116 /$ hc0502.10333

22. Lemieux I, Pascot A, Prud'homme D, Almeras N, Bogaty P, Nadeau $\mathrm{A}$, et al. Elevated C-reactive protein: another component of the atherothrombotic profile of abdominal obesity. Arterioscler Thromb Vasc Biol. 2001;21:961-7.

23. Christian LM, Glaser R, Porter K, Malarkey WB, Beversdorf D, Kiecolt-Glaser JK, et al. Poorer self-rated health is associated with elevated inflammatory markers among older adults. Psychoneuroendocrinology. 2011;36(10):1495-504. doi:10.1016/1.psyneuen.2011.04.003.

24. Heinrich PC, Castell JV, Andus T. Interleukin-6 and the acute phase response. Biochem J. 1990;265(3):621-36. do1:10.1042/b|2650621]

25. Meyer AA, Kundt G, Steiner M, Schuff-Werner P, Kienast W Impaired flow-mediated vasodilation, carotid artery intima-media thickening, and elevated endothelial plasma markers in obese children The impact of cardiovascular risk factors. Pediatrics. 2006;117:1560 7

\section{Author biography}

Ch Bhadra Reddy, Associate Professor

Kunachgi Preeti Nagkumar, Associate Professor

M Hima Bindu, Associate Professor

Chinthaparthi Mallikarjuna Reddy, Associate Professor

Cite this article: Reddy CB, Nagkumar KP, Bindu MH, Reddy CM. Association between obesity and $\mathrm{c}$ reactive protein among patients with risk factors for cardiovascular disease. IP Indian J Immunol Respir Med 2021;6(2):121-124. 